\title{
Trophic complexity in marine sediments: new evidence from the Gulf of St. Lawrence
}

\author{
Pedro A. Quijónn ${ }^{1, *}$, Paul V. R. Snelgrove ${ }^{2}$ \\ ${ }^{1}$ Department of Biology, University of Prince Edward Island, 550 University Avenue, Charlottetown, \\ Prince Edward Island C1A 4P3, Canada \\ ${ }^{2}$ Ocean Sciences Centre and Biology Department, Memorial University of Newfoundland, St. John's, \\ Newfoundland A1C 5S7, Canada
}

\begin{abstract}
The potential for predatory infaunal species to increase trophic complexity in marine sedimentary habitats has been debated in the past; however, the status of predatory infauna as a distinct trophic level remains controversial. Specifically, it is unclear whether these assemblages can be accurately depicted by a 3-level trophic model in which predatory infauna constitutes a critical intermediate trophic link between epibenthic predators and other infauna. Here, we specifically address whether the key requirement for recognition of a 3-level trophic structure (namely that 'epibenthic predators must selectively prey on predatory infauna') is supported by new experimental evidence from 2 contrasting habitats in the Gulf of St. Lawrence, Canada. Our results unambiguously support a 3-trophic level model and raise a series of questions on the current understanding of the trophic structure of marine sedimentary habitats.
\end{abstract}

KEY WORDS: Trophic complexity $\cdot$ Predatory infauna $\cdot$ Soft sediments

\section{INTRODUCTION}

The notion that predatory infauna plays a crucial role in structuring marine sedimentary communities (e.g. Commito \& Ambrose 1985, Schubert \& Reise 1986, Kneib 1991, Desroy et al. 1998) has direct implications for understanding trophic complexity in these and other unstructured habitats (Thrush 1999). Until the 1980s, the role played by epibenthic predators such as fish, shorebirds, and crabs was based on the assumption that the entire infaunal community functions largely as a single trophic compartment. Ambrose (1984a) rejected the simple 2-level (epibenthos-infauna) trophic structure and proposed that predatory infauna represents a critical trophic link that mediates the effects of epibenthic predators on infaunal communities. Wilson (1986) questioned much of the experimental evidence provided by Ambrose (1984a) and established one necessary condition (which, in his view, was not met by Ambrose's review) to validate a 3-level trophic model, namely that epibenthic predators must prey preferentially on predatory as opposed to non-predatory infaunal species. An array of subsequent studies has provided indirect support (Bick \& Arlt 1993, Rönn et al. 1998, Hiddink et al. 2002), or have failed to support (McArthur 1998) this 3-level trophic model. Thus, 2 decades later, and despite the broad trophic implications of such different views, this debate has not moved forward (cf. Òlafsson et al. 1994, Thrush 1999, Lenihan \& Micheli 2001).

\section{MATERIALS AND METHODS}

Although Ambrose (1984a) identified more than one mechanism to explain an increase in the proportion of predatory infauna in the absence of epibenthic predators, i.e. (1) preferential predation on predatory infauna by epibenthic predators, (2) increased predation by predatory infauna on non-predatory infauna, 
irrespective of the preferences of epibenthic predators, and (3) competitive reduction of non-predatory infauna by predatory infauna, Wilson (1986) determined that the first mechanism was the only necessary (critical) condition for validation of a 3-level trophic model. Our study focuses on this mechanism and assesses its existence by re-visiting some of our past experiments that examined the influence of epibenthic decapods on western Newfoundland subtidal communities (Quijón \& Snelgrove 2005a,b) and by examining more recent data from the southern Gulf of St. Lawrence (Basin Head, Prince Edward Island; P. Quijón unpubl. data). Specifically, we compare the effects of predation on abundances of predatory and non-predatory species using several different data sets gathered with similar tools and sampling protocols (cf. Quijón \& Snelgrove $2005 a, b)$. As in the original studies by Ambrose (1984a, 1986 and references therein) and Wilson (1986), we compare simple metrics such as the ratio of predators: non-predators in sediments exposed to predation and those that are not.

In addition to predator-exclusion comparisons, we also examine the results of a small-scale natural comparison (sensu Diamond 1986) between undisturbed muddy sediments and similar sediments affected by predation from non-native green crabs, and predatorinclusion experiments conducted in the field (snow crab and green crab) and in the laboratory (snow crab and rock crab; Table 1). As we reported previously, all of these experiments detected significant changes in infaunal total densities caused by crab predation. However, we further dissect those results to assess whether these changes can, in fact, be attributed to preferential feeding of epifauna on predatory infauna. Based on literature available on feeding/functional groups (e.g. Fauchald \& Jumars 1979, Josefson 1985), the predatory infauna in our experiments was dominated primarily by polychaetes of the genera Nereis, Pholoe, Phyllodoce, Eteone, Nephtys, Aglaophamus, Glycera, Goniada, and Hartmania, and, to a lesser extent, nemerteans). Type of experiment, duration, habitat, depth, treatments, and replication are summa- rized in Table 1. In field exclusions and inclusions, counts of organisms in ambient versus predatormanipulated sediments were compared at the end of each experiment with 1-way ANOVA. In all the analyses, ANOVA assumptions were properly tested and in those cases where the data did not fit those assumptions, they were square root transformed. Similar analyses were used to compare infaunal densities in sediments associated with fresh (1 d old) feeding pits on the natural seafloor versus undisturbed sediments. Laboratory experiments used block designs that allowed comparison of sediments exposed and protected from crab predation, while controlling for tank effect and number of crabs per tank (1 or 2) separately for each species (cf. Quijón \& Snelgrove 2005a,b).

\section{RESULTS AND DISCUSSION}

The differences summarized in Fig. 1 and Table 2 clearly reflect the preference of crabs for predatory infauna ( $p \leq 0.020$ in all 7 analyses that compare sediments protected from predation and those exposed to predation) in contrast with results for non-predatory infauna ( $p>0.05$ in 5 of 7 comparisons; these individuals were proportionally less affected by predation than predatory infauna in all 7 comparisons). The exclusion of predators on average (Fig. 1A,B) resulted in a $\sim 395 \%$ increase in predatory organisms inside cages, compared to a change of less than $5 \%$ in ambient sediments. The non-manipulative experiment that compared sediments in fresh feeding pits of green crab to ambient sediments (Fig. 1C) also showed stronger effects on predatory than non-predatory infauna (decreases of 57.8 and $36.3 \%$, respectively). Similarly, field inclusions of snow or green crabs (Fig. 1D,E) resulted in prey density reductions that were 4 to 5 times greater than reductions for predatory species. In laboratory experiments, these preferences were also evident with snow crabs as epifaunal predators (reductions of 62.9 versus $8.4 \%$ for predatory versus non-predatory infaunal species, respectively). In the

Table 1. Type of manipulation, duration, and experimental setting (habitat, treatments, and replication) for different sets of experiments

\begin{tabular}{|lclll|}
\hline Type of manipulation & Duration & Habitat & Treatments & Replication \\
\hline (A) Short-term exclusion & $4 \mathrm{wk}$ & Sandy $(30 \mathrm{~m})$ subtidal & Cages vs. ambient & $\mathrm{n}=4$ \\
(B) Mid-term exclusion & $8 \mathrm{wk}$ & Sandy $(30 \mathrm{~m})$ subtidal & Cages vs. ambient & $\mathrm{n}=4$ \\
(C) Green crab feeding pits & $1 \mathrm{~d}$ & Muddy intertidal & Pits vs. ambient & $\mathrm{n}=8$ \\
(D) Snow crab field inclusion & $4 \mathrm{~d}$ & Sandy $(15 \mathrm{~m})$ subtidal & Cages vs. ambient & $\mathrm{n}=4$ \\
(E) Green crab field inclusion & $4 \mathrm{~d}$ & Muddy intertidal & Cages vs. ambient & $\mathrm{n}=8$ \\
(F) Snow crab laboratory inclusion & $4 \mathrm{~d}$ & Fresh sediment with infauna & 1-2 crab vs. ambient & $\mathrm{n}=9$ \\
(G) Rock crab laboratory inclusion & $4 \mathrm{~d}$ & Fresh sediment with infauna & 1-2 crab vs. ambient & $\mathrm{n}=9$ \\
\end{tabular}



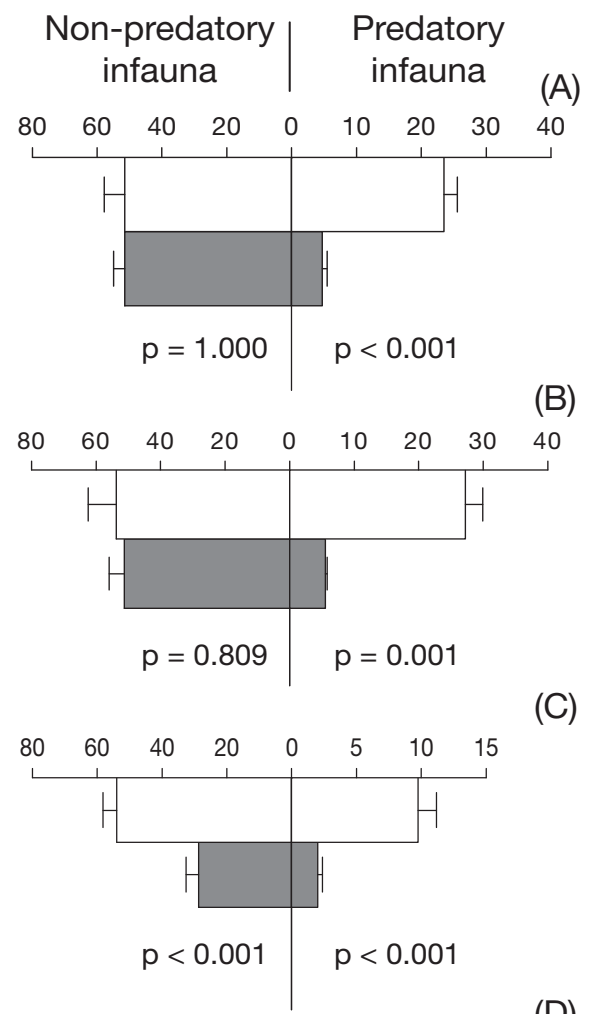

(C)

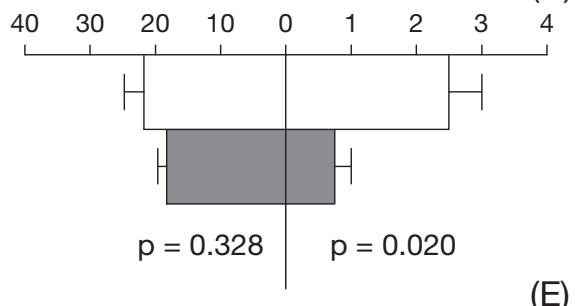

(E)

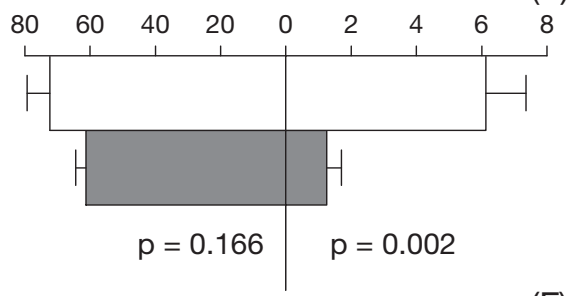

(F)

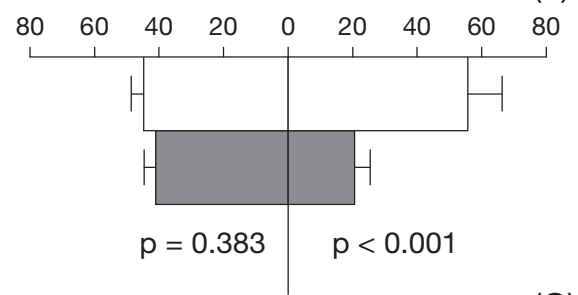

(G)

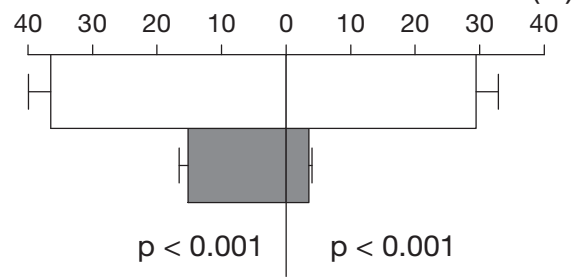

case of rock crabs, such differences were also clear but less striking ( 87.9 versus $58.4 \%$ ), a result probably related to their disproportionately strong effects as predators (cf. Òlafsson et al. 1994). In these rock crab laboratory experiments specifically, sediments exposed to predation had 4 times fewer organisms and nearly $50 \%$ fewer species than non-exposed sediments (Quijón \& Snelgrove 2005b). In the laboratory manipulations (Fig. 1F,G, Table 2), the alternative sources of variation (tank and crab number) were relevant in only 1 case (1 versus 2 snow crabs); however, predator number did not affect the overall treatment effect on predatory versus non-predatory infauna. Ratios of predatory to non-predatory infauna comparable to those used by Ambrose (1984a) and Wilson (1986) (Table 3) corroborate the results described above, i.e. that the guild of predators and the individual crab species in manipulative experiments had an unambiguous preference for predatory infauna. In rock crab experiments, these predatory:non-predatory infaunal ratios were between 2.5 and 5 times lower in sediments exposed to epibenthic predation.

The evidence presented here is by no means exhaustive, but provides strong support for a 3-level trophic structure model in sedimentary habitats. Our results also extend the validity of this model to sandy sediments, a habitat where Ambrose (1984a, 1986) and subsequent authors have not found supporting evidence for this model. The consistency of these results is also remarkable considering that they come from contrasting habitats (15 to $30 \mathrm{~m}$ deep coarse sandy sediments in Newfoundland and intertidal muddy-sand sediments in Prince Edward Island), and from the manipulation of either an entire guild of predators (exclusions) or individual epibenthic predators (snow crab, green crab, rock crab) in the laboratory or in the field. The use of an array of experimental approaches enhances our ability to identify ecological patterns and processes (Thrush et al. 1997) and arrival at similar outcomes after their execution strengthens the robustness of our conclusions. Nonetheless, caution must be exercised in extrapolation of these conclusions to con-

Fig. 1. Effects of crab predation on mean densities (+SE) of non-predatory (left) and predatory infauna (right). Open bars denote infauna not/less exposed to crab predation (i.e. treatments without predator added or controls exposed to natural predator pressure only). Solid bars denote infauna exposed to predators. (A) Short-term exclusion, (B) Mid-term exclusion, (C) Ambient versus freshly disturbed sediments (green crab feeding pits); (D) $4 \mathrm{~d}$ snow crab field inclusion; (E) $4 \mathrm{~d}$ green crab field inclusion; (F) 4 d snow crab lab inclusion; (G) 4 d rock crab lab inclusion. p values refer to treatment effects on predatory and non-predatory fauna separately. See Table 1 for further information on each manipulation 
Table 2. Summary of statistical analyses comparing the effect of treatment upon non-predatory and predatory infauna separately (same degrees of freedom apply to both analyses). For simplicity, only MS and $F$ values are presented. Significant differences, where detected, are ${ }^{*} \mathrm{p}<0.05_{i}{ }^{* *} \mathrm{p}<0.01$

\begin{tabular}{|llrrrrr|}
\hline \multirow{2}{*}{$\begin{array}{l}\text { Type of } \\
\text { manipulation }\end{array}$} & Source & df & \multicolumn{2}{c}{ Non-predatory } & \multicolumn{2}{c|}{ Predatory infauna } \\
& & & MS & $F$ & MS & $F$ \\
\hline (A) Short-term & Treatment & 1 & 0.0 & 0.0 & 703.1 & $73.1^{* *}$ \\
exclusion & Error & 6 & 102.7 & & 9.6 & \\
(B) Mid-term & Treatment & 1 & 12.5 & 0.1 & 946.1 & $40.6^{*}$ \\
exclusion & Error & 6 & 195.6 & & 23.3 & \\
(C) Green crab & Treatment & 1 & 2970.2 & $22.9^{* *}$ & 240.3 & $28.2^{* *}$ \\
feeding pits & Error & 14 & 129.8 & & 8.5 & \\
(D) Snow crab field & Treatment & 1 & 24.5 & 1.1 & 6.1 & $9.8^{*}$ \\
inclusion & Error & 6 & 21.6 & & 0.6 & \\
(E) Green crab field & Treatment & 1 & 495.1 & 2.1 & 95.1 & $13.8^{*}$ \\
inclusion & Error & 14 & 232.1 & & 6.9 & \\
(F) Snow crab lab & Treatment & 1 & 128.4 & 0.8 & 2756.3 & $26.5^{* *}$ \\
inclusion & Tank & 2 & 84.2 & 0.5 & 252.6 & 2.4 \\
& Crab no. & 1 & 2952.1 & $18.0^{* *}$ & 6806.3 & $65.5^{* *}$ \\
& Error & 31 & 12.0 & & 103.8 & \\
(G) Rock crab lab & Treatment & 1 & 6534 & $74.5^{* *}$ & 3700 & $47.4^{* *}$ \\
inclusion & Tank & 2 & 97.0 & 1.1 & 59.19 & 0.8 \\
& Crab no. & 1 & 156.3 & 1.8 & 56.25 & 0.7 \\
& Error & 31 & & & 78.07 & \\
\hline
\end{tabular}

Table 3. Proportional effects on infaunal densities of manipulating (removal or inclusion) epibenthic predators. Predatory:non-predatory infaunal ratios are also presented for the corresponding treatments (exposed or less exposed to epibenthic predators)

\begin{tabular}{|lcccc|}
\hline $\begin{array}{l}\text { Type of } \\
\text { manipulation }\end{array}$ & \multicolumn{2}{c}{$\begin{array}{c}\text { Proportional effects } \\
\text { on prey density (\%) }\end{array}$} & \multicolumn{2}{c|}{$\begin{array}{c}\text { Predatory:non- } \\
\text { predatory infauna ratios } \\
\text { Exposed }\end{array}$} \\
\hline $\begin{array}{c}\text { Less exposed } \\
\text { (A) Short-term } \\
\text { exclusion }\end{array}$ & +394.7 & +0.0 & 0.092 & $<0.456$ \\
$\begin{array}{c}\text { (B) Mid-term } \\
\text { exclusion }\end{array}$ & +395.5 & +4.9 & 0.107 & $<0.507$ \\
$\begin{array}{c}\text { (C) Green crab } \\
\text { feeding pits }\end{array}$ & -79.5 & -46.8 & 0.070 & $<0.181$ \\
$\begin{array}{c}\text { (D) Snow crab } \\
\text { field inclusion }\end{array}$ & -35.0 & -8.0 & 0.041 & $<0.115$ \\
$\begin{array}{c}\text { (E) Green crab } \\
\text { field inclusion }\end{array}$ & -79.6 & -15.4 & 0.020 & $<0.085$ \\
$\begin{array}{c}\text { (F) Snow crab } \\
\text { lab inclusion }\end{array}$ & -62.9 & -8.4 & 0.252 & $<0.621$ \\
$\begin{array}{c}\text { (G) Rock crab } \\
\text { lab inclusion }\end{array}$ & -87.9 & -58.4 & 0.234 & $<0.807$ \\
\hline
\end{tabular}

trasting habitats or sites at different latitudes, since they were based on manipulative experiments conducted at relatively small scales and were focused primarily on crabs as epibenthic predators. Different environments require directed experiments to determine how broadly this trophic structure model can be applied. As stated by both Ambrose (1984a) and Wilson (1986), the applicability of a single model may vary among habitats where different complements of epibenthic predators and predatory and non-predatory species co-occur. It would be particularly interesting to test this model at latitudes where a substantially larger number of epibenthic predators resides year-round rather than seasonally. Furthermore, a 3-level trophic structure does not restrict the role of intermediate predators to infaunal predators, in that this role may be filled instead by small epibenthic predators (vertebrates or invertebrates) or a combination of both (Kneib 1991).

Three alternative mechanisms may account for changes in predatory infaunal abundance in response to epibenthic predation. First, if there are pervasive differences between life history traits (primarily r-selected non-predatory species as opposed to primarily $\mathrm{K}$ selected predatory species), then faster colonization by non-predatory infauna may explain the proportionally lower number of predatory infauna within inclusion cages. We consider this an unlikely explanatory mechanism because a large proportion of the nonpredatory infauna displays K-selected traits (sensu McCall 1977), and includes low-mobility species (bivalves, sedentary worms) that could not respond within the time scales of our manipulations. Second, if there are differences in body size (larger predatory infauna as opposed to smaller non-predatory infauna), non-selective epibenthic predators probing the sediments would be more likely to encounter predatory infauna than non-predatory infauna. Most of our experiments identified relatively large non-predatory infauna (e.g. clams such as Astarte sp.), which contradicts a size-based interpretation. Third, physical disturbance of the sediment by the feeding and displacement of many epibenthic predators may account for some of the infaunal mortality and may potentially modify predatory:non-predatory ratios. Sediment disturbance, however, is likely more detrimental to sedentary or low-mobility species, than to the highly motile species that are typical for predatory infauna (e.g. Bick \& Arlt 1993).

In view of the generality of a 3-level trophic model (at least in the systems we studied), the apparent absence of trophic cascades in marine soft sediments 
(Pace et al. 1999, Posey et al. 2002, but see Ambrose 1984b and Daborn et al. 1993) is intriguing. There are no clear explanatory mechanisms for this absence of trophic cascades, but we propose 3 distinct features of infaunal communities that are of relevance: (1) high prey mobility (Frid 1989) and its ability to swamp the effects of predation (Thrush 1999); (2) widespread omnivory and facultative trophic habits (Hiddink et al. 2002); and (3) high trophic complexity within the predatory (Desroy et al. 1998) and/or non-predatory components of the infauna (Raffaelli \& Hall 1992). This complexity creates a challenge in deciphering and predicting the outcomes of trophic interactions and points to a strong need for more studies on the natural history of sediment-dwelling species.

Acknowledgements. We thank C. Peterson and 2 anonymous reviewers for their comments on an earlier version of the manuscript. We also thank several students for their help in the field, particularly M. Norris, M. Kelly, K. MacMillan, K. Brown and V. Lutz-Collins. Funding was provided by individual Discovery Grants from the Natural Sciences and Engineering Council of Canada (NSERC) to P.A.Q. and P.V.R.S. We are also thankful for the support received from UPEI-Office of Research and Development (P.A.Q), and the Canada Research Chair in Boreal and Cold Ocean Systems (P.V.R.S).

\section{LITERATURE CITED}

Ambrose WG Jr (1984a) Role of predatory infauna in structuring marine soft bottom communities. Mar Ecol Prog Ser 17:109-115

Ambrose WG Jr (1984b) Influences of predatory polychaetes and epibenthic predators on the structure of a soft-bottom community in a Maine estuary. J Exp Mar Biol Ecol 81: $115-145$

Ambrose WG Jr (1986) Importance of predatory infauna in marine soft-bottom communities: reply to Wilson. Mar Ecol Prog Ser 32:41-45

Bick A, Arlt G (1993) The influence of Hediste diversicolor (O.F. Müller, 1776) on the macro- and meiozoobenthos of a shallow water area of Mecklenburg Bay (Western Baltic Sea). Rostock. Rostock Meeresbiol Beitr 1:9-24

Commito JA, Ambrose WG Jr (1985) Multiple trophic levels in soft-bottom communities. Mar Ecol Prog Ser 26:289-293

Daborn GR, Amos CL, Brylinsky M, Christian H and others (1993) An ecological cascade effect: migratory birds affect stability of intertidal sediments. Limnol Oceanogr 38: 225-231

Desroy N, Retiere C, Thiebaut E (1998) Infaunal predation regulates benthic recruitment: an experimental study of the influence of the predator Nepthys hombergii (savigny) on recruits of Nereis diversicolor (O.F. Müller). J Exp Mar Biol Ecol 228:257-272

Diamond J (1986) Overview: laboratory experiments, field experiments, and natural experiments. In: Diamond J, Case TJ (eds) Community ecology. Harper \& Row, New York, p 3-22

Fauchald K, Jumars PA (1979) The diet of worms: a study of

Editorial responsibility: Robert Feller,

Columbia, South Carolina, USA polychaete feeding guilds. Oceanogr Mar Biol Annu Rev $17: 193-284$

Frid CLJ (1989) The role of recolonization processes in benthic communities, with special reference to the interpretation of predator induced effects. J Exp Mar Biol Ecol 126: 163-171

Hiddink JG, ter Hofstede R, Wolff WJ (2002) Predation of intertidal infauna on juveniles of the bivalve Macoma balthica. J Sea Res 47:141-159

Josefson AB (1985) Distribution of diversity and functional groups of marine benthic infauna in the Skagerrak (eastern North Sea) - can larval availability affect diversity? Sarsia 70:229-249

Kneib RT (1991) Indirect effects in experimental studies of marine soft-bottom communities. Am Zool 31:875-885

Lenihan HS, Micheli F (2001) Soft-sediment communities. In: Bertness M, Hay M, Gaines S (eds) Marine community ecology. Sinauer, Sunderland, MA, p 253-287

McArthur VE (1998) Predation and the survival of juvenile Cerastoderma glaucum Bruguere (Mollusca: Bivalvia) in a coastal lagoon. J Exp Mar Biol Ecol 225:79-97

McCall PL (1977) Community patterns and adaptive strategies of the infaunal benthos of Long Island Sound. J Mar Res 35:221-266

Òlafsson EB, Peterson CH, Ambrose WG Jr (1994) Does recruitment limitation structure populations and communities of macroinvertebrates in marine soft-sediments: the relative significance of pre- and post-settlement processes. Oceanogr Mar Biol Annu Rev 32:65-109

Pace ML, Cole JJ, Carpenter SR, Kitchell JF (1999) Trophic cascades revealed in diverse ecosystems. Trends Ecol Evol 14:483-488

Posey MH, Alphin TD, Cahoon LB, Lindquist DG, Mallin MA, Nevers MB (2002) Top-down versus bottom-up limitation in benthic infaunal communities: direct and indirect effects. Estuaries 25:999-1014

Quijón PA, Snelgrove PVR (2005a) Predation regulation of sedimentary faunal structure: potential effects of a fisheryinduced switch in predators in a Newfoundland sub-arctic fjord. Oecologia 144:125-136

> Quijón PA, Snelgrove PVR (2005b) Differential roles of crustacean predators in a subarctic soft-sediment system. Mar Ecol Prog Ser 285:137-149

Raffaelli D, Hall SJ (1992) Compartments and predation in an estuarine food web. J Anim Ecol 61:551-560

Rönn C, Bonsdorff E, Nelson WG (1988) Predation as a mechanism of interference within infauna in shallow brackish water soft bottoms; experiments with an infaunal predator, Nereis diversicolor, O.F. Müller. J Exp Mar Biol Ecol 116:143-157

Schubert A, Reise K (1986) Predatory effects of Nephtys hombergii on other polychaetes in tidal flat sediments. Mar Ecol Prog Ser 34:117-124

> Thrush SF (1999) Complex role of predators in structuring soft-sediment macrobenthic communities: implications of changes in spatial scale for experimental studies. Aust J Ecol 24:344-354

Thrush SF, Schneider DC, Legendre P, Whitlatch RB and others (1997) Scaling-up from experiments to complex ecological systems: Where to next? J Exp Mar Biol Ecol 216:243-254

Wilson WH Jr (1986) Importance of predatory infauna in marine soft-sediment communities. Mar Ecol Prog Ser 32:35-40

Submitted: March 25, 2008; Accepted: August 12, 2008

Proofs received from author(s): November 13, 2008 